Richard W. Spinrad, Editor

\section{The Lighthouse that is Scripps}

This is the largest issue of Oceanography ever published. That fact, in itself, is testimony to the magnitude of the tribute that this issue represents. One hundred years is, arguably, not a particularly long time. However some claim that this period represents the majority of the history of oceanography as a discipline, and certainly the era during which most of our scientific and technical accomplishments have been realized. Consequently, it is a great honor for The Oceanography Society, and for me, personally, to have this magazine serve a primary role in the chronicling of the evolution of Scripps Institution of Oceanography over the last century.

Editing this issue of Oceanography has been a special treat. Every one of the articles contained herein has a distinct flavor of passion and affection not normally found in the pages of this magazine. My usual editorial approach of dispassion was simply not possible this time. Instead of spending my typical two hours reviewing each manuscript, I found myself absorbed in the text and the images for three or more hours in every case. Warning to the reader: your imagination will take control as you read these articles!

Ask a literate bystander what we've learned about the earth and its oceans in the last hundred years, and he or she will likely include such topics as climate (i.e. global climate change or coupled ocean-atmosphere systems or biogeochemical cycling), fisheries (i.e. living marine resources), oil and gas (i.e. non-living resources), undersea topography (i.e. tectonics and geophysics), and many others (although I venture to guess that this literate bystander would use slightly different jargon!). Then leaf through these pages and you will find wonderful descriptions of the role that Scripps researchers have played in laying much of the scientific foundation for what we have learned in one hundred years in each of these areas.

A final note. When the staff at Scripps first approached the Council of The Oceanography Society with a proposal to dedicate an issue of this magazine to the Scripps centennial, there was some concern about setting a precedent for the magazine to do the same for other oceanographic institutions. My message now is simple: what an outstanding precedent to set!

To all of the Scripps 'family' I wish you fair winds and following seas as you cruise into your second century.

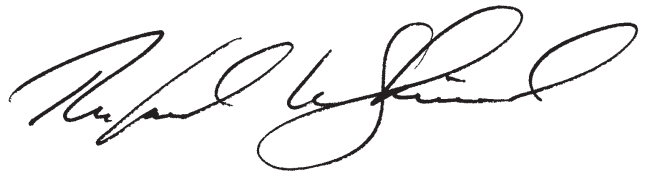

Www.tos.org

EDITOR

Richard W. Spinrad

National Ocean Service

SSMC 41305 East-West Highway

Silver Spring, MD

(301) 713-3074

richard.spinrad@noaa.gov

ASSISTANT EDITOR

Elizabeth J. Tirpak

magazine@tos.org

ASSOCIATE EDITORS

Gregg J. Brunskill

Australian Institute of Marine Science

PMB No. 3, Townsville, M.C.

Queensland 4810, Australia

(61) 747534481 Fax: (61) 747725852 g.brunskill@aims.gov.au

Ellen R.M. Druffel

Department of Earth System Science

222 Roland Hall University of California

Irvine, California 92697-3100 USA

(949) 824-2116 Fax: (949) 824-3256

edruffel@uci.edu

Charles H. Greene

Director, Ocean Resources and Ecosystems Program

Department of Earth \& Atmospheric Sciences

Cornell University

2130 Snee Hall

Ithaca, New York 14853-2701

(607) 255-5449 Fax: (607) 254-4780

chg2@cornell.edu

James Syvitski

Director, Institute of Arctic and Alpine Research

University of Colorado at Boulder

1560 30th Street, Campus Box 450

Boulder, Colorado 80309-4050 USA

(303) 492-7909 Fax: (303) 492-6388

james.syvitski@colorado.edu

Peter Wadhams

Scott Polar Research Institute University of Cambridge

Lensfield Road

Cambridge CB2 1ER England

+44 1223-336542 Fax: +44 1223-336549

pw11@phx.cam.ac.uk

\section{DESIGN/PRINTING}

Corporate Press

403 Brightseat Road

Landover, Maryland 20785 USA 